\title{
Reformism, Class Conciliation and the Pink Tide: Material Gains and Their Limits
}

\author{
Pedro Mendes Loureiro
}

\section{INTRODUCTION}

Towards the end of a long period of developmental regimes, from roughly 1930 to 1980, Latin America became the world's laboratory for neoliberalism, pioneering transitions in Chile and Argentina in the early and mid-1970s. This soon spread to most of the continent, and, alongside a crisis-ridden decade of the 1980s, Latin America underwent the most thorough neoliberal transformation in the world (Sader 2011). Countries across the region promoted trade and financial liberalisation, cut the already small welfare entitlements and privatised state assets, whilst firms integrated themselves into low-value-added sections of global value chains (Medeiros 2011). What resulted was an unstable, low-growth model dependent on foreign direct investment, as well as rising unemployment, labour market informality, poverty and inequality.

Towards the end of the 1990s, popular approval of neoliberal governments consequently fell and, starting with Venezuela in 1998, many

The author would like to thank Alfredo Saad-Filho, Ben Fine and Leandro Vergara-Camus for the invaluable discussions that helped shape this chapter, as well as Coordenação de Aperfeiçoamento de Pessoal de Nível Superior (Capes) for the grant [BEX 1669/14-1] that made this research possible.

P.M. Loureiro $(\square)$

SOAS, University of London, London, UK

(C) The Author(s) 2018

M. Ystanes, I.Å. Strønen (eds.), The Social Life of Economic

Inequalities in Contemporary Latin America, Approaches to Social

Inequality and Difference, DOI 10.1007/978-3-319-61536-3_2 
countries elected presidents running on platforms allegedly antithetical to neoliberalism. This continental movement, known as the 'Pink Tide', made use of particularly positive global conditions to deliver material gains. Relatively fast growth rates in central countries, the strong Chinese demand for commodities underpinning its breakneck development and abundant international liquidity combined to benefit low- and middle-income economies (Saad-Filho 2013). Left-leaning Latin American governments capitalised on this moment to implement economic planning initiatives and novel welfare policies, such as conditional cash transfers (CCTs). These latter policies were financed mostly through higher taxation of soaring commodity exports. Under a changed economic and social policy mix, growth rates picked up and social conditions improved, partially reverting the negative consequences of neoliberalism and cementing popular support.

The Pink Tide would soon ebb, however, in a spiral of economic and political crises. Governments could not continue to deliver social improvements when, under deteriorating international conditions, tougher distributional choices had to be made. Combined with allegations of corruption and the repression of worker and indigenous struggles, important constituencies were alienated and a growing sense of disillusionment took hold. Traditional right-wing parties furthermore took hold of these scenarios to reorganise themselves and regain power. Several left-of-centre governments have thus been, legally or not, ousted from power since the 2009 Honduran military coup against Manuel Zelaya. This picked up speed with the 2015 right-wing victory of Mauricio Macri in Argentina and the 2016 parliamentary coup against Dilma Rousseff in Brazil.

In light of the Pink Tide's unravelling, the moment thus seems ripe for an appreciation of the significance of this historical moment and what it entailed. This chapter attempts to offer such a contribution: understanding to which extent have the Pink Tide governments implemented or not a clear break with neoliberalism and contributed to launching a sustained process of material gains for the working classes in Latin America. In order to do so, it discusses the economic and political trends prevailing in the continent as a whole, focusing on changes to the productive structure of the economies, the new matrix of social policies and the political strategies carried out to keep these governments in power. These three dimensions can be respectively synthesised in a shift towards neo-extractivism, or the renewed dependence on the export of primary commodities; the rise of conditional cash transfer policies (CCTs) as the main form of social safety nets; and the establishment of broad electoral fronts and a neo-corporatist 
pattern of class relations, which is to say, a state-centred mediation of capital-labour-social movements relations.

The main argument of this chapter is that the Pink Tide governments have indeed promoted changes that economically benefitted the working classes, but they could not secure the sustainability of this process. As explored below, the very processes that led to better standards of living reinforced a precarious international insertion of the countries, as they stimulated a neo-extractivist pattern of accumulation. Politically, the governments' strategies disorganised the working classes and social movements, as they depended on class conciliation measures and the repression of independent struggles. Without, furthermore, a clear battle for ideas and a vision of the future, the terrain on which the struggle was to be fought became shallow, limited to defending material gains. Therefore, these improvements were not accompanied by self-reinforcing economic and political conditions, but rather by an increased likelihood of any situation of crisis being 'solved' via an exclusionary shift in policies or government. In broad terms, the forces behind these governments have advanced an 'inconsequential' attempt at counter-hegemony, which relied too much on short-term factors and did not transform the state, the economy and prevalent ideas in ways that would progressively establish structural conditions compatible with popular goals.

The argument can be divided into four elements. First, there were substantial material gains for the working classes not entirely ascribable to positive international economic conditions, but partially due to active government policies, especially minimum wage hikes and CCTs.

Second, to bring about these improvements, the governments (i) relied on and promoted a neo-extractivist pattern of accumulation; (ii) reproduced themselves politically via broad fronts, centrally relying on neocorporatist class conciliation measures, cash transfers to the most destitute groups and the repression of struggles by groups not aligned to the government, and (iii) did not promote far-reaching transformations of the state institutionality, of class relations or of visions about the trajectories development should assume.

Third, neo-extractivism and neo-corporatist class conciliation eroded the sustainability of this process, as they respectively (i) cemented a peripheral insertion in the world market and a class structure with a sizeable amount of precarious employment and (ii) disorganised the working classes and social movements, which were then incapable of mounting (extrainstitutional) pressure. Finally, it therefore became increasingly likely that, when these social formations faced a crisis, it would not be the progressive 
elements in these hybrid state forms to be deepened. On the contrary, a transformation of state power in an exclusionary direction was to be expected, as indeed has been happening throughout the region.

The remainder of the chapter is structured as follows. The second section reviews the changing productive structure and international insertion of Latin American economies, differentiating between national experiences where possible. This comprised the rising importance of extractive activities and deindustrialisation, leading to a re-primarisation of exportsthat is, the decrease of manufactured goods and the rise of low-valueadded, unprocessed commodities in total exports. The third brings forth the class structures associated to this pattern of accumulation and changes to the standards of living. It is shown that the latter improved and there was reduced labour informality, but also structural precariousness in face of the poor quality of the jobs created.

The text then covers the changes to the state form, in two steps. The section 'The Changing Character of State Power: A Neo-corporatist Mediation of Class Relations' shows how the Pink Tide governments were neo-corporatist, as they attempted to directly mediate class relations by bringing them into the state apparatus. The support for domestic capitalists and the dissemination CCTs, which reduced poverty and inequality, are highlighted. The section 'Class Conciliation, Demobilisation and Repression' then explores the political underpinnings of this class conciliation process, namely, the incorporation $\mathrm{cum}$ co-option of social movements and class entities into the state and the repression of independent struggles. The section 'Final Remarks' summarises and concludes the chapter, underscoring the inherent limits to the non-confrontational strategy advanced by the Pink Tide.

\section{The Productive Structure: Neo-extractivism AND DEINDUSTRIALISATION}

Neoliberalism and the debt crisis of the 1980s promoted deep transformations to the economy of Latin America. The continent's growth rate, on average 5.8 and never below 3.0 per cent between 1961 and 1980, dropped to 2.3 per cent between 1981 and 2000, with several years of negative or near-zero growth (World Bank 2015). At the same time, the region's insertion in the world market was made more precarious, with manufacturing decreasing substantially (see below). The abandonment of active industrial policies and the trade and financial opening were the main factors 
behind this (Bogliaccini 2013), leading to greater vulnerability and the recurrent crises of the 1990s.

Since the 2000s, however, the renewed dependence on the extraction and export of primary commodities has been the central feature of the Latin American economy. This has been variously described as a neoextractivist pattern of accumulation (Veltmeyer 2013; Webber 2014), a reprimarisation of the structure of exports (Gonçalves et al. 2009) or, indeed, a commodities consensus (Svampa 2013). The central feature this characterisation conveys is that the extraction and export of primary goods has become the driving element of capital accumulation in Latin America. This does not imply such activities are the largest element of GDP, but rather that they are the main dynamic force in the economic cycle.

Estimations show how the foreign sector drove the growth of Latin American economies during the 2000s, led by commodity exports (Caldentey and Vernengo 2010). ${ }^{1}$ Accordingly, agricultural and extractive commodities have risen from 41 to 53 per cent of total Latin American exports between 1999 and 2013, whilst manufacturing decreased from 58 to 44 per cent (Ray et al. 2015, 5). If the centrality of unprocessed commodity exports is similar to 'old' extractivism, what qualifies it as neoextractivism is, in turn, the greater participation of the state in these activities, essentially via taxation on which social policies are funded (Arsel and Angel 2012; Arsel 2012; Gudynas 2012).

The implications of this process can be felt at different levels. On a local scale, the communities directly affected by extractive projects are subjected to environmental degradation and a destabilisation of their social reproduction, given that very few benefits spill over (Veltmeyer 2013). This heightens the spatial inequality of accumulation and sponsors processes of accumulation by dispossession, in which transnational companies, guarded by state power, continuously advance over natural resources. This amounts to the expanded commodification of nature and the forced proletarianisation of small farmers and peasants (Webber 2014).

On a macro level, the results are more complex. The currency inflows obtained with commodity exports present both opportunities and risks, which can be analysed under the so-called Dutch disease and the possibilities of avoiding it. The risks exist insofar as a rapid inflow of money, generally due to higher export prices, might appreciate the domestic currency (i.e., make foreign currency, and thus also foreign-produced goods, cheaper) and thus decrease the international competitiveness of the manufacturing sector. As imports become cheaper, domestic manufacturers are forced out 
of business, which forestalls the diversification of the economy and decreases the quality of available jobs (Bresser-Pereira 2011; Frenkel and Rapetti 2012). Once this boom is over, the economy would find itself in a worse position, given that the production of commodities generates less and worse-quality jobs and does not promote technological upgrading. This is what is referred to as the Dutch disease, but it is not, it should be stressed, a necessary outcome of higher export prices. Given appropriate policies, the currency overvaluation can be checked and the resources directed to developmental objectives (Saad-Filho and Weeks 2013).

The actual results are mixed. On the one hand, higher commodity exports helped sustain growth (for a look into the different transmission mechanisms, see Ocampo 2009). Every single Latin American country accumulated a substantial amount of foreign reserves, and with the exception of Jamaica and Barbados the same happened for the Caribbean. Altogether, the region's gross international reserves increased from US\$ 163 billion in 2001 (ECLAC 2010, 272) to US\$ 830 billion in 2013 (ECLAC 2014, 191). Moreover, higher growth rates and taxation of exports provided resources for social policies. ${ }^{2}$ On the other hand, except for Argentina, the region's exchange rates were overvalued during the 2000s (Frenkel and Rapetti 2012). Hence, the turn to neo-extractivism has contributed to an already existent and ongoing process of deindustrialisation (Bresser-Pereira 2011; Brady et al. 2011).

Following the initial dismantling of manufacturing under neoliberal governments, there thus was a 'standing still', defensive policy that perpetuated deindustrialisation. The region has, moreover, also been specialising in less competitive manufacturing sectors, which means that the manufacturing sectors and jobs that did manage to remain are lagging behind world competitors (CEPAL 2007; Cimoli et al. 2010). Consequently, whilst the Pink Tide governments cannot be held responsible for initiating deindustrialisation, their rule deepened it due to the reliance on a neo-extractivist pattern of accumulation.

Summing up, under the pressure of the commodities boom, virtually all Latin American countries shifted to neo-extractivism. If this allowed for financing social policies and alleviated the balance-of-payments constraint, it also entailed negative environmental consequences, spurred deindustrialisation and heightened mid-term external vulnerability. In other words, the Pink Tide marked an inflection with regard to the neoliberal governments insofar as they used a positive international scenario to finance social goals, but no greater breaks were to be found. Deindustrialisation was deepened, without any prospect for improving the region's peripheral 
position in the global market and the problems of its economic structure. The chapter now explores how this reflected on changing class structures, employment patterns and the standards of living of the population.

\section{Class Structures and Standards of Living Under THE Pink Tide}

During the neoliberal period, there was a general tendency towards greater inequality and labour precarisation in Latin America, with five major trends (Portes and Hoffman 2003; Robinson 2008; Cornia 2012). First, unemployment rose substantially and tended to remain high. Second, particularly for Central American and Caribbean countries, a migrant labour class grew and, with it, numerous households came to rely on remittances. Labour market informality was another main trend, which also took the form of precarious self-employment and micro-entrepreneurialism. This was associated to the fourth trend, widespread labour deregulation. Finally, the feminisation of labour was present throughout.

These processes had clear impacts in terms of inequality, poverty and wages. The Gini index of household per capita income, the most common measure of inequality, increased by 0.05 between the early 1980s and 2002 (Cornia 2012,4). This represented an increase of approximately 10 per cent, starting from what was already a very high level. Poverty followed suit, as the proportion of the population below the poverty line increased from 40.5 to 44 per cent between 1980 and 2002 (Robinson 2008, 252). In absolute terms, this meant 84 million more people living in poverty. As for wages, the real minimum wage dropped on average 30 per cent between 1980 and 1990 and was mostly stagnant until 2000 (ILO 2002, 115).

In the beginning of the century, however, at least a partial reversal of these trends was underway, as poverty, income inequality and informality undoubtedly decreased (Cornia 2014; Lustig et al. 2013). During the 2000 s, inequality decreased by almost the same amount it had increased in the previous two decades. Thus, the average Gini coefficient for Latin America fell by 0.04 between 2002 and 2010. Another way of looking at this is that the share of national income appropriated by the richest 10 per cent of the population decreased in almost all countries, whereas the bottom 50 per cent got more (Cornia 2012, 4). ${ }^{3}$ The proportion of the urban population living in poverty decreased very substantially, more than reverting the neoliberal trend: poverty dropped 14 percentage points between 2002 and 2012 (ECLAC 2014, 137). There were also striking 
differences in terms of labour informality. If 80 per cent of the jobs created during the 1990s were in the informal sector, informality dropped by about 8 per cent during the 2000s (ILO 2013). Finally, real minimum wages increased, on average, by 54 per cent between 2000 and 2012 (ILO 2013, 127). This holds for all Latin American countries, with the exception of the Dominican Republic.

Importantly, there is strong evidence that these developments were in large measure due to government policies (Cornia 2012, 2014). In a study of 18 Latin American countries to explain what caused the changes to income inequality, Cornia $(2012,37)$ finds that external conditions and economic growth were of minor importance. The main factors responsible for the decrease of inequality were greater access to secondary education, higher minimum wages and lower labour informality, and greater government transfers. Government policies such as increasing the minimum wage and instituting conditional cash transfers were, therefore, central to the decrease of inequality.

Furthermore, the left-of-centre governments were seen to have reduced inequality considerably more than the rest. The broad left, including Bolivia under Evo Morales, Brazil under the Partido dos Trabalbadores (Brazilian Workers' Party, PT) and Venezuela, all decreased their levels of inequality during the 2000s. As for centre and centre-rights administrations, such as Uruguay in the first half of the 2000s and Mexico, there were mixed results and in some of them inequality rose. On average, the decrease was much slower for countries not under the Pink Tide governments (Cornia 2012).

In light of this, it is clear that the Pink Tide governments positively impacted the living standards of the working classes. These results discredit interpretations that ascribe to foreign conditions the direct determinant of improved living standards, such as considering that the commodities boom would have had positive results regardless of the orientation of the governments in power. As seen above, domestic political choices were key. That inequality and living standards improved more rapidly under the Pink Tide is also of central importance. The issue is then to explore the limits of this process.

\section{The Changing Character of State Power: A NeO-corporatist Mediation of Class Relations}

If the neoliberal state was mainly the enforcer of market discipline on capital and labour, under the Pink Tide it took on a more flexible character, which attempted to mediate (intra-)class relations via economic and social 
policies and negotiation procedures. A useful way of looking at this is through tripartite negotiation forums, or negotiation tables between state representatives, capital and labour to determine wages and working conditions. This meant, first, that capital-labour relations were explicitly brought into the state. This was predicated upon a more direct participation of state power in the relations between capitalists of different economics sectors, as well as in the reproduction of labour power. As regards the former, the main element was the attempt to steer accumulation towards a 'national development project', for which the governments had to prioritise the relevant sectors and companies. This was done, for example, by actively using procurement policies to stimulate domestic firms, offering tax subsidies for strategic sectors and the like. As for workers, a significant increase in social policies, however not universal, and rising minimum wages were key. Finally, as these processes of class conciliation reached their limits, the continued repression of 'hardliner' popular organisations ensued (see the examples of the TIPNIS march and the repression of Piqueteros below).

This state form, on the one hand, was capable of securing greater gains (as compared to the neoliberal state) for the working classes, as seen in the previous section. On the other hand, as its legitimacy was strictly associated to securing the profitability of various fractions of capital and certain gains for the working classes, it was largely dependent on maintaining high growth rates. It was thus inherently prone to destabilisation as growth faltered. Furthermore, this commitment to negotiation and the conciliatory dynamics it implied made it incapable of promoting wide-ranging transformations. In short, it secured certain gains for the working classes whilst preventing greater transformations: it could manage neoliberalism in a relatively progressive direction, but not break with it. These developments are reviewed in order.

In the transition to neoliberalism, state power was used to push the privatisation of state-owned enterprises (SOEs), market liberalisation and the rollback of sector-specific policies, such as discontinuing subsidies for strategic sectors or state-run research and development initiatives. Thereafter, it sought to advance the integration of national economies to the world market, privileging the interests of financial forms of capital and arbitrating less between other fractions. Likewise, the state did not participate directly in wage negotiations, but rather repressed workers' mobilisations. Therefore, competing in a globally integrated market became the central locus of class relations and the way to achieve wage gains or higher profitability, and state power actively enforced this (Bonnet and Piva 2012). 
On the other hand, under the Pink Tide state power assumed more the role of an arbiter. Negotiation forums were central in this process. Through these, class representatives and social movements entered into negotiation processes with the government and capitalists, so that issues related to distributional conflicts, wage levels, investment priorities and so on were addressed in an explicitly politicised and state-centred manner (Bonnet and Piva 2012; Piva 2011). ${ }^{4}$

There are three main results that came from this neo-corporatist pattern of organising class relations. First, to a certain extent it routinised social conflicts and directed capitalist accumulation strategies towards potentially developmental objectives (such as a pro-poor growth pattern, or growth with high wages). Second, it directly politicised accumulation, as state power came to be seen as responsible for the material outcomes of the various class fractions. Third, and as a consequence of this, the legitimacy of governments became increasingly attached to securing modest gains for the relevant classes-bankruptcies of industrialists, for example, could no longer be 'explained away' as a result of inefficient competition (as in the 1990s), but become a directly political problem. As governments' legitimacy came to depend on securing - and being held responsible for-these material gains, the strategies below were put in place to tend to capitalists and the population at large.

With the Pink Tide, there was a recovery of state planning capacities and, in some cases, a partial re-nationalisation of formerly privatised SOEs. This is what many authors (Leiva 2008; Bresser-Pereira 2011; Féliz 2012) saw as a neodevelopmental state form, which actively intervened via subsidies and tax exemptions to stimulate particular economic sectors, used development banks to finance domestic firms, took on a greater role in providing infrastructure and other public goods and so on. In short, the neodevelopmental state attempted to steer accumulation towards a pattern compatible with a particular - and always selective-view of what national development would be (Boito Jr and Berringer 2014; Féliz 2012; Petras and Veltmeyer 2007). National development came to be associated, in particular, with the accumulation strategies of the internal bourgeoisie, ${ }^{5}$ and this class fraction displaced the hegemonic position of transnationalised financial capital (Boito Jr and Berringer 2014).

Differently from the 'traditional' Latin American developmental state of the mid-twentieth century, however, the neodevelopmental state did not seek to overcome the countries' position in the world market; it was a 
watered-down version of its precursor (Leiva 2008). Thus, growth rates were lower, the structure of the economy (in terms of the predominant sectors) did not change substantially, and the local capitalists politically behind this state form were not interested in antagonising those of developed countries. In Boito Jr's and Berringer's words, 'neodevelopmentalism is the developmentalism of the era of neoliberal capitalism [...] the development policy that is possible within the limits of the neoliberal capitalist model' (2014, 97, emphasis in the original). In this sense, it was an inflection within neoliberalism, but not a break with the latter.

The neo-corporatist state also had to guarantee at least moderately rising living standards for the working classes, if some stability was to obtain. The main instruments employed were raising minimum wages and CCTs. The latter did increase profusely, whilst universal social safety nets and public services showed little improvement. In 2013, CCTs were present in 20 countries and reached approximately 120 million people, or 20 per cent of the region's population (Cecchini 2013). On the positive side, there is strong evidence that they were indeed able to reach the poor and very poor. There is also no evidence that if properly designed, they significantly stimulated labour market segmentation and informality, increased the fertility rate of beneficiaries (Stecklov et al. 2007) or reduced labour market participation (Alzúa et al. 2013). That they have lifted millions out of poverty at a very low cost of approximately 0.4 per cent of the region's GDP is no mean feat (Cecchini and Madariaga 2011).

In spite of this positive record for CCTs, the claims about their capacity of achieving longer-term goals-breaking the inter-generational transmission of poverty - are much harder to sustain, and as of yet there is no evidence in this regard (Valencia Lomelí 2008; Handa and Davis 2006). Moreover, given the small amount of the benefits provided, in most cases poverty vulnerability has not been adequately addressed, and improvements in the labour market were more important in reducing inequality. Finally, cheap though they might be, their cost-effectiveness is by no means demonstrated, given leakages and higher administrative costs as compared to universal programmes (Saad-Filho 2015). The extension of CCTs can thus be considered a welcome, if far from sufficient, development. Their widespread recommendation by the World Bank (Fiszbein et al. 2009) is a further indication that this form of social policy is safely within the realm of neoliberal policymaking. 


\section{Class Conciliation, Demobilisation and Repression}

As regards the strictly political relation between the government and class entities, a two-sided process was in place. It comprehended, first, incorporating or co-opting the representatives of trade unions and social movements, who would participate in negotiation forums. As a corollary, it also involved isolating or repressing independent entities. The central element was thus 'convincing' labour and social movements to abandon extrainstitutional mobilisation and direct action in favour of official channels. As part of this, many leaders of trade unions and social movements were incorporated into the state apparatus, assuming offices (Oliveira et al. 2010; Farthing and Kohl 2014). This amounted to a routinisation of social conflicts and the possibility of sharing, to an extent, in the gains capital enjoyed, albeit at the price of curtailing the tools popular sectors can use in their struggles (see examples below).

The second element was dividing class entities and social movements into 'good', negotiating ones, and 'bad', independent ones (Castorina 2013; Webber 2014; Galvão 2014). A line was thus drawn between the demands that could be processed and those that had to be ignored and repressed. This 'us versus them' approach created divisions within the popular sectors, and thus further restricted the horizons of what was at stake in official negotiations (Modenesi 2012). Combined as it was to actively repressing all forms of independent struggle, it led to demobilisation and less independent grassroots organising. Ironically, then, in the mid-term they hampered the continuity of reforms by hindering popular mobilisation from below, an important element in obtaining concessions from capital. This combination of improved material conditions without political empowerment, promoting instead class conciliation, is another illustration of the limits of the inflection under the Pink Tide.

All of these were widespread processes, of which three examples are offered. In Brazil, after the PT came to power, it appointed many union leaders to key positions in the state apparatus. The Central Única dos Trabalhadores (CUT), the main trade union federation, became organically linked to the routine management of the state. Once a combative and innovative organisation, it was already moderating itself throughout the 1990s; with the PT in power, however, it clearly opted for a negotiating strategy and abandoned tactics reliant on wide mobilisations of its base (Galvão 2014). As for the Movimento dos Trabalhadores Rurais sem Terra (MST), they did not establish organic links with the government, but likewise opted 
for a negotiating strategy in which the resort to direct action was strongly curtailed. As a militant put it, 'When government is ours, it's worse. The MST stops organizing protests' (Vergara-Camus 2009, 186). Finally, independent struggles were met with indifference to their demands, repression and police violence. The countrywide 2012 strike of federal university workers is a good example, but the response to the mobilisations of 2013 is the strongest. What came to be known as Jornadas de Junho were the first mass demonstrations in the country for decades, with millions of participants and outside the influence of government-aligned trade unions and social movements. Police violence caused them to grow and continued to be present throughout their whole unfolding, but was never condemned by president Dilma Rousseff, and their demands were not met (Moraes et al. 2014).

In Argentina, the introduction of Plan Jefes y Jefas de Hogar (PJyJH), a CCT programme, had important implications for the unemployed workers organisations known as Piqueteros, hitherto at the forefront of popular resistance to neoliberalism and the 2001-2002 crisis (Castorina 2013). The government selectively incorporated the leaders of certain organisations into the state apparatus to administer PJyJH benefits whilst repressing those that did not cooperate. 'Good Piqueteros' thus became government allies and received the power to administer cash transfers, and 'bad' ones were alienated and dwindled. This destroyed horizontal linkages between the various grassroots movements, but at the same time stabilised conflicts. As for labour struggles, the Labour and Social Development ministries were reinstated as the site of tripartite negotiations, with important implications for moderating workers' strategies. This state-sponsored negotiating strategy could bring important trade unions along, such as the Confederación General del Trabajo de la República Argentina (CGT) (Bonnet and Piva 2012; Bonnet 2012).

In the case of Bolivia a similar process of incorporation and repression took place. On the one hand, various organisations that formed the basis of the Movimiento al Socialismo (Movement Towards Socialism (MAS), the left governing party since 2006) have become part of the state apparatus and opted for institutional-based forms of struggle. The leaders of entities representing indigenous movements and trade unions, such as the Confederación Sindical Única de Trabajadores Campesinos de Bolivia (CSUTCB), have assumed several positions in office (Farthing and Kohl 2014). This 'de-colonisation' of the state, a central platform of the MAS government, has arguably led many marginalised groups to see themselves 
reflected in the state apparatus and allowed for real gains in negotiation processes (Ikemura Amaral 2014).

This incorporation of historically excluded groups in Bolivia comes with a caveat, nevertheless. When social movements understand the state is not acquiescing to their demands and go for direct action-which, it must be remembered, stands behind the insurrectionary movement that culminated in MAS's rise to power (Webber 2011) - they have been deemed 'imperialist conspiracies' or the agents of foreign NGOs, and are repressed. The clearest example of this process came in the wake of the conflicts around the TIPNIS national park (Territorio Indígena y Parque Nacional Isiboro Sécure), when mostly indigenous groups protested against government plans to build a motorway through it. As SanchezLopez reports, 'the government disqualified the legitimacy of this civic action arguing that the indigenous organizations were manipulated by the "oligarchy elites, the green imperialism of Western NGOs and the US government"' and brutally repressed them (Sanchez-Lopez 2015, 24).

This whole process receives its perhaps clearest expression in the thought of Álvaro García Linera, Bolivia's vice-president and a prolific theoretician. As he puts it, 'the Bolivian people have consolidated their historical unity around a single project for the state, the economy and the society' (García Linera 2011, 7, our emphasis). In fact, since the consolidation of the revolutionary process we would be witnessing the dissolution of the state form into society, creating an 'integral state' (p. 10). The government and its allies would thus concentrate in themselves all the 'creative tensions' of the revolution, the only paths capable of further advancing popular goals (p. 28). The corollary is that every mobilisation not contained within these limits, such as those of communities that resist extractivism, must of necessity be denounced as particularistic, counterproductive or even imperialist (Webber 2014). The state form is thus the arbiter of all that is progressive, and there are only two positions: one is either for it, and (critically) supports it from within, or a right-wing agent of counter-revolution. No progressive stance outside of the state's realm is possible. Whilst García Linera restricts his analysis to Bolivia, it can arguably be extended to encompass the strategies and rhetoric of various other Pink Tide governments. ${ }^{6}$

\section{FinAL Remarks}

Latin America underwent a multifaceted process of social change that defies all summary interpretations. Neither a clear continuity with the immediately preceding neoliberal past nor a deep-rooted break with it, the 
Pink Tide was a nuanced and internally differentiated inflection. There were undeniable material gains for the popular classes, as inequality, poverty and labour informality levels decreased, in large measure due to the political initiative of Pink Tide governments. This occurred, nevertheless, under very particular foreign conditions, given the coincidence of the high international commodity prices and capital flows to less-developed economies. Whilst the latter did not determine the processes indicated above, they do seem to have played a contradictory enabling role, and their overall impact is still far from clear. Additionally, the Pink Tide governments promoted problematic economic and political developments, which sapped the potential for a continued process of gains for the population.

The main inflections in the pattern of accumulation, social policies and the state form can be respectively described as the rise of neo-extractivism, the expansion of CCTs and minimum wage hikes and the transition to a neocorporatist state. Neo-extractivism or the commodity consensus (Veltmeyer 2013; Svampa 2013) thus highlights the centrality of commodity exports, as well as the state's role in fostering them. This is linked to the idea of a compensatory state (Gudynas 2012), which taxed such activities to promote CCTs and minimum wage hikes. If this brought about material gains, it fell short, however, of instituting universal safety nets or de-commodifying basic needs, underscoring the limits of the transformations that took place. Finally, neo-corporatism suggests a state form that internalised class conflicts, circumscribing them to what was compatible with the then-prevailing pattern of accumulation. This is seen as an attempt to promote class conciliation by distributing material gains to various social movements and class fractions, whilst moderating their goals (Bonnet and Piva 2012).

A synthesis is proposed combining elements from these three dimensions-neo-extractivism, the expansion of CCTs and minimum wage hikes and the transition to a neo-corporatist state. This is intended both as a general interpretive framework of the Pink Tide governments and, more importantly, as a framework for comparing the different experiences within the continent. The main thread that runs through these dimensions is that, to different degrees, the Pink Tide governments chose the paths of least resistance in trying to advance a reformist project. They restricted their goals, adopted tactics consistent with this and delivered what was possible under these circumstances: some gains to the working classes when compared to the neoliberal past, but without promoting structural changes and at the cost of preventing popular empowering. Lower informality combined to precarious employment, reducing inequality but only to the levels of the 1980s, and achieving higher growth rates 
whilst cementing a peripheral insertion in the world market are illustrative. These were undoubtedly important inflections, but not strong enough breaks to institute self-sustaining processes that would endure. ${ }^{7}$

In this vein, there was a strategic complementarity between neoextractivism, a CCT-based social policy mix and neo-corporatism. These were all mechanisms for social compromise that, compared to the preceding phase of strict neoliberalism, allowed for relatively greater gains for the working classes. The inherent downside, however, was that they prevented popular empowering, contentious politics and a clearer break with the prevailing productive and class structure. Whilst it is beyond the scope of this chapter to try to discern the precedence or causation of each of these elements, it is argued that over time, through a trial-and-error process, they reinforced and supported each other. As neo-extractivism offered funding for CCTs, there was interest in stimulating commodity exports; CCTs together with rising real minimum wages sustained popular approval of the governments; and faster growth with lower inequality legitimated neo-corporatist, conciliatory class relations-which, in turn, helped guarantee the interests of local capitalists and so on.

This strategic complementary also explains the brittleness of the Pink Tide, as pursuing paths of least resistance eroded the political and economic resilience of these countries and hence made them vulnerable to destabilisation. The point is that there was a tendency for these forms (neo-extractivism, CCT-based social policies and neo-corporatism) to develop alongside each other and forestall alternatives in any single dimension. Why go for independent labour mobilisation when neo-corporatism was delivering wage gains? Why attempt a larger overhaul of macroeconomic policies if there had been growth and this would require confronting powerful interests? Fundamentally, how could any of these possibilities obtain without strong popular organisation? Attempting to change one dimension without supporting transformations in the others was hence extremely unlikely. The different elements were thus likely to stand and fall together, in the latter case particularly if subjected to foreigndetermined shocks, of which the fall in commodity prices offers a prime example.

It is thus no surprise that, as foreign conditions worsened in the early and mid-2010s, the social formations found themselves in a debilitated position and the processes that sustained these governments in power were no longer operative. The predictable crisis that ensued thus did not lead to a deepening of the progressive elements in these hybrid state forms, 
particularly given the demobilisation of popular forces, but rather to exclusionary adjustments. Which is to say, instead of trying to solve the crises via public investment in infrastructure, tax reforms to redistribute money to the poor and so on, austerity measures were instead called for. This is diametrically opposed to the neoliberal crises of the late 1990s, which occurred in the wake of long-term processes of popular organisation and eventually led to the election of left-of-centre governments.

In the medium term, these paths of least resistance ironically went from being the most realistic options to utopic ones. They eroded their conditions of existence, without promoting structural economic and political transformations that could deepen their progressive impact. This underscores the dangers of broad political fronts and minimalist reformist programmes. Their very condition of success in the short term-appealing to a broad section of the population and avoiding overt conflict-prevents them from confronting established interests, particularly capitalist ones. On the contrary, the dynamics that unfold are all geared towards class conciliation and incremental reforms, thwarting more transformative actions and the very continuity of such already-diminished goals.

\section{Notes}

1. In Central America, remittances are the driving factor, which can be conceptualised as an export of labour (Robinson 2008; Caldentey and Vernengo 2010). Brazil is an outlier in terms of its drivers of growth, which were domestic after 2006 (Serrano and Summa 2015), but the commodities boom was still central as it provided reserves that displaced the balance-ofpayments constraint to growth.

2. There is regional variation in the channels that connected higher exports to taxation and social policies. For example, Bolivia directly increased royalties and taxes on natural gas exports and earmarked some of these proceeds for social programmes. In Brazil, on the other hand, it was higher growth rates and labour formalisation that allowed the government to increase spending (Serrano and Summa 2015).

3. In Peru, for example, the 10 per cent richest got about 7 per cent less of national income between 2002 and 2009, whereas the bottom 50 per cent got about 3 per cent more. Costa Rica, Nicaragua and Colombia are the only exceptions to this trend (Cornia 2012).

4. Traditionally, corporatism refers to negotiation forums between organised labour, firm representatives and state managers. The distinction for Latin America, which merits the neo- qualifier, is the presence of social movements. 
5. A Poulantzian concept, their interests are somewhat tied to accumulation in the domestic or regional market, as opposed to fully transnationalised class fractions, but not to the extent of the now-defunct national bourgeoisie (Boito Jr and Berringer 2014, 95).

6. As Sader (2013) put it for Brazil: 'This group, which allegedly took to the left of the PT to found PSOL [Partido Socialismo e Liberdade], quickly added itself, in a subordinate manner, to the right-wing attack on the government. [...] The extreme left [...] has, tacitly or explicitly, allied itself with the right against these [Pink Tide] governments.'

7. It is beyond the scope of this chapter to analyse the political alternatives and draft a different programme, which would in any case depend strongly on the conjuncture. Nevertheless, three general elements are central: timing, structural transformations and extra-institutional mobilisation. A pragmatic approach was arguably necessary in the initial moments of the Pink Tide governments, and the feasibility of openly class-confrontational programmes is indeed debatable. To overcome this, entrenching transformations of the economy and political institutions would be essential (such as universalising public services, preventing private financing of political campaigns and so on). When these governments enjoyed massive popular support, for example, towards the end of Lula's second term in Brazil (2010), these changes could be attempted. Popular mobilisation would be a means of pressuring for them, and this would in turn firmly cement the support basis of the parties. The precise changes and moments are sure to vary, but by merely managing the state without transforming, it the Pink Tide governments would increasingly trap themselves in a corner.

\section{REFERENCES}

Alzúa, María Laura, Guillermo Cruces, and Laura Ripani. 2013. Welfare Programs and Labor Supply in Developing Countries: Experimental Evidence from Latin America. Journal of Population Economics 26 (4): 1255-1284.

Arsel, Murat. 2012. Between 'Marx and markets'? The State, the 'Left Turn' and Nature in Ecuador. Tijdschrift voor economische en sociale geografie 103 (2): $150-163$.

Arsel, Murat, and Natalia Avila Angel. 2012. "Stating” Nature's Role in Ecuadorian Development: Civil Society and the Yasuní-ITT Initiative. Journal of Developing Societies 28 (2): 203-227.

Bogliaccini, Juan Ariel. 2013. Trade Liberalization, Deindustrialization, and Inequality: Evidence from Middle-Income Latin American Countries. Latin American Research Review 48 (2): 79-105.

Boito, Armando, Jr., and Tatiana Berringer. 2014. Social Classes, Neodevelopmentalism, and Brazilian Foreign Policy Under Presidents Lula and Dilma. Latin American Perspectives 41 (5): 94-109. 
Bonnet, Alberto. 2012. La crisis del Estado neoliberal en la Argentina. In El estado en América Latina: continuidades y rupturas, ed. Mabel Thwaites Rey, 279-302. Santiago: Editorial ARCIS.

Bonnet, Alberto, and Adrián Piva. 2012. Un análisis de los cambios en la forma de estado en la posconvertibilidad. In Argentina después de la convertibilidad (2002-2011), ed. Juan Grigera, 3-31. Buenos Aires: Imago Mundi.

Brady, David, Yunus Kaya, and Gary Gereffi. 2011. Stagnating Industrial Employment in Latin America. Work and Occupations 38 (2): 179-220.

Bresser-Pereira, Luiz Carlos. 2011. An Account of New Developmentalism and Its Structuralist Macroeconomics. Revista de economia politica 31 (3): 493-502.

Caldentey, Esteban Pérez, and Matías Vernengo. 2010. Back to the Future: Latin America's Current Development Strategy. Journal of Post Keynesian Economics 32 (4): 623-644.

Castorina, Emilia. 2013. Crisis and Recomposition in Argentina. In The New Latin American Left. Cracks in the Empire, ed. Jeffery R. Webber and Barry Carr, 233-254. Plymouth: Rowman \& Littlefield.

Cecchini, Simone. 2013. Transferências condicionadas na América Latina e Caribe: da inovação à consolidação. In Programa Bolsa Família: uma década de inclusão e cidadania, ed. Tereza Campello and Marcelo Cortês Neri, 367-396. Brasília: IPEA.

Cecchini, Simone, and Aldo Madariaga. 2011. Conditional Cash Transfers Programmes: The Recent Experience in Latin America and the Caribbean. Santiago: ECLAC.

CEPAL. 2007. Progreso técnico y cambio estructural en América Latina. Santiago: Naciones Unidas.

Cimoli, Mario, Gabriel Porcile, and Sebastián Rovira. 2010. Structural Change and the BOP-Constraint: Why Did Latin America Fail to Converge? Cambridge Journal of Economics 34 (2): 389-411.

Cornia, Giovanni Andrea. 2012. Inequality Trends and Their Determinants: Latin America Over 1990-2010, 1-46, WIDER Working Papers (2012/09).

- ed. 2014. Falling Inequality in Latin America: Policy Changes and Lessons. Oxford: Oxford University Press.

ECLAC. 2010. Economic Survey of Latin America and the Caribbean 2009-2010: The Distributive Impact of Public Policies. Santiago: ECLAC.

- 2014. Economic Survey of Latin America and the Caribbean 2014: Challenges to Sustainable Growth in a New External Context. Santiago: ECLAC.

Farthing, Linda C., and Benjamin Kohl. 2014. Evo's Bolivia: Continuity and Change. Austin: University of Texas Press.

Féliz, Mariano. 2012. Neo-developmentalism: Beyond Neoliberalism? Capitalist Crisis and Argentinas Development Since the 1990s. Historical Materialism 20 (2): 105-123.

Fiszbein, Ariel, Norbert Schady, Francisco H.G. Ferreira, Margaret Grosh, Niall Keleher, Pedro Olinto, and Emmanuel Skoufias. 2009. Conditional Cash 
Transfers: Reducing Present and Future Poverty. World Bank Policy Research Report. Washington, DC: World Bank.

Frenkel, Roberto, and Martin Rapetti. 2012. External Fragility or Deindustrialization: What Is the Main Threat to Latin American Countries in the 2010s? World Economic Review 1: 37-57.

Galvão, Andréia. 2014. The Brazilian Labor Movement Under PT Governments. Latin American Perspectives 41 (5): 184-199.

García Linera, Alvaro. 2011. Las tensiones creativas de la revolución: la quinta fase del proceso de cambio. La Paz: Vicepresidencia del Estado Plurinacional de Bolivia.

Gonçalves, Reinaldo, Marcelo Dias Carcanholo, Luiz A.M. Filgueiras, and Eduardo Costa Pinto. 2009. Vulnerabilidad estructural externa en América Latina. In Los condicionantes de la crisis en América Latina: inserción internacional y modalidades de acumulación, ed. Enrique O. Arceo and Eduardo M. Basualdo, 119-138. Buenos Aires: CLACSO.

Gudynas, Eduardo. 2012. Estado compensador y nuevos extractivismos: las ambivalencias del progresismo sudamericano. Nueva Sociedad 237: 128-146.

Handa, Sudhanshu, and Benjamin Davis. 2006. The Experience of Conditional Cash Transfers in Latin America and the Caribbean. Development Policy Review 24 (5): 513-536.

Ikemura Amaral, Aiko. 2014. Os caminhos da politização da indigeneidade: um estudo sobre a identidade indigena na política boliviana pós-1985. Mestrado em Ciência Política Dissertação, Departamento de Ciência Política, Universidade de São Paulo.

ILO. 2002. 2002 Labour Overview Latin America and the Caribbean. Lima: ILO. . 2013. 2013 Labour Overview Latin America and the Caribbean. Lima: ILO.

Leiva, Fernando Ignacio. 2008. Latin American Neostructuralism: The Contradictions of Post-Neoliberal Development. Minneapolis/London: University of Minnesota Press.

Lustig, Nora, Luis F. Lopez-Calva, and Eduardo Ortiz-Juarez. 2013. Declining Inequality in Latin America in the 2000s: The Cases of Argentina, Brazil, and Mexico. World Development 44 (0): 129-141.

Medeiros, Carlos Aguiar. 2011. The Political Economy of Institutional Change and Economic Development in Latin American Economies. Journal of Economic Issues XLV (2): 289-300.

Modenesi, Massimo. 2012. Revoluciones pasivas en América Latina: una aproximación gramsciana a la caracterización de los gobiernos progresistas de inicio del siglo. In El estado en América Latina: continuidades y rupturas, ed. Mabel Thwaites Rey, 139-166. Santiago: Editorial ARCIS.

Moraes, Alana, Bernardo Gutiérrez, Henrique Parra, Hugo Albuquerque, Jean Tible, and Salvador Schavelzon, eds. 2014. Junho: potência das ruas e das redes. São Paulo: Friedrich Ebert Stiftung (FES) Brasil. 
Ocampo, José Antonio. 2009. Latin America and the Global Financial Crisis. Cambridge Journal of Economics 33 (4): 703-724.

de Oliveira, Francisco, Ruy Braga, and Cibele Saliba Rizek, eds. 2010. Hegemonia às avessas: economia, politica e cultura na era da servidão financeira. São Paulo: Boitempo.

Petras, James, and Henry Veltmeyer. 2007. The 'Development State' in Latin America: Whose Development, Whose State? Journal of Peasant Studies 34 (3): 371-407.

Piva, Adrián. 2011. Una aproximación a los cambios en la Forma de Estado en Argentina (2002-2009). Theomai: estudios sobre sociedad, naturaleza y desarrollo 23: 1-23.

Portes, Alejandro, and Kelly Hoffman. 2003. Latin American Class Structures: Their Composition and Change During the Neoliberal Era. Latin American Research Review 38 (1): 41-82.

Ray, Rebecca, Kevin P. Gallagher, Andres Lopez, and Cynthia Sanborn, eds. 2015. China in Latin America: Lessons for South-South Cooperation and Sustainable Development. Boston: Boston University's Global Economic Governance Initiative (GEGI).

Robinson, Wiiliam I. 2008. Latin America and Global Capitalism. A Critical Globalization Perspective. Baltimore: The John Hopkins University Press.

Saad-Filho, Alfredo. 2013. Mass Protests Under 'Left Neoliberalism': Brazil, June-July 2013. Critical Sociology 39 (5): 657-669.

- 2015. Social Policy for Neoliberalism: The Bolsa Família Programme in Brazil. Development and Change 46 (6): 1227-1252.

Saad-Filho, Alfredo, and John Weeks. 2013. Curses, Diseases and Other Resource Confusions. Third World Quarterly 34 (1): 1-21.

Sader, Emir. 2011. The New Mole: Paths of the Latin American Left. London: Verso.

- 2013. Por que a extrema esquerda fracassou. Blog do Emir. Accessed 5 Feb 2015.

Sanchez-Lopez, Daniela. 2015. Reshaping Notions of Citizenship: The TIPNIS Indigenous Movement in Bolivia. Development Studies Research 2 (1): 20-32.

Serrano, Franklin, and Ricardo Summa. 2015. Aggregate Demand and the Slowdown of Brazilian Economic Growth in 2011-2014. Nova Economia 25 (especial): 803-833.

Stecklov, Guy, Paul Winters, Jessica Todd, and Ferdinando Regalia. 2007. Unintended Effects of Poverty Programmes on Childbearing in Less Developed Countries: Experimental Evidence from Latin America. Population Studies 61 (2): 125-140.

Svampa, Maristella. 2013. Consenso de “commodities” y lenguajes de valoración en América Latina. Nueva Sociedad 244: 30-46. 
Valencia Lomelí, Enrique. 2008. Conditional Cash Transfers as Social Policy in Latin America: An Assessment of Their Contributions and Limitations. Annual Review of Sociology 34 (1): 475-499.

Veltmeyer, Henry. 2013. The Political Economy of Natural Resource Extraction: A New Model or Extractive Imperialism? Canadian Journal of Development Studies/Revue canadienne d'études du développement 34 (1): 79-95.

Vergara-Camus, Leandro. 2009. The Politics of the MST: Autonomous Rural Communities, the State, and Electoral Politics. Latin American Perspectives 36 (4): 178-191.

Webber, Jeffery R. 2011. Red October: Left-Indigenous Struggles in Modern Bolivia. Leiden: Brill.

- 2014. Revolution Against 'Progress': Neo-extractivism, the Compensatory State, and the TIPNIS Conflict in Bolivia. In Crisis and Contradiction: Marxist Perspectives on Latin America in the Global Political Economy, ed. Susan Spronk and Jeffery R. Webber, 302-333. Leiden: Brill.

World Bank. 2015. World Bank Open Data. Accessed 4 May 2015.

Open Access This chapter is licensed under the terms of the Creative Commons Attribution 4.0 International License (http://creativecommons.org/licenses/ by $/ 4.0 /$ ), which permits use, sharing, adaptation, distribution and reproduction in any medium or format, as long as you give appropriate credit to the original author(s) and the source, provide a link to the Creative Commons license and indicate if changes were made.

The images or other third party material in this chapter are included in the chapter's Creative Commons license, unless indicated otherwise in a credit line to the material. If material is not included in the chapter's Creative Commons license and your intended use is not permitted by statutory regulation or exceeds the permitted use, you will need to obtain permission directly from the copyright holder.

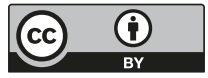

